\title{
Yrittäjyyskasvatuksen uusia tuulia
}

Paula Kyrö ja Anna Ripatti (toim.). Yrityskasvatuksen uusia tuulia. Tampereen yliopiston Kauppakorkeakoulu, Yrittäjyyskasvatuksen julkaisusarja 4/2006.

\section{Yrittäjyyskasvatuksen uusia} tuulia -teos jatkaa suomalaisen yrittäjyyskasvatuksen toimitettujen teosten perinnettä. Aiemmin ilmestyneitä artikkelikokoelmia ovat mm. Matti Parikan toimittama Kasvu yrittäjyyteen vuodelta 1997 ja Paula Kyrön, Kari E. Nurmen ja Tuulia Tikkasen toimittama Yrittäjyyden askeleita yhteiskunnassa vuodelta 1999. Tällaisten, useista artikkeleista koostuvien toimitettujen teosten suhteellinen osuus on lisääntynyt kasvatustieteidenkin piirissä.

Suuntauksessa on kuitenkin omat ongelmansa erityisesti opetuksen kannalta: artikkelikokoelmat eivät läheskään aina sovellu luontevasti oppikirjoiksi. Artikkelimuoto edellyttää tiivistä ilmaisua, joka ei useinkaan salli monimutkaisten sisältöasioiden perusteellista selittämistä ja esimerkkien avulla tapahtuvaa havainnollistamista. Koska myös artikkeleiden lähtökohdat, näkökulmat, tasot ja muut erityispiirteet vaihtelevat yleensä keskenään, ei aiheeseen vasta perehtyvälle opiskelijalle välttämättä muodostu ehyttä kokonaiskuvaa käsiteltävästä asiasta.

Teoksen I osa Yliopistossa tuulee - yrittäjyyden opetus vahvistuu keskittyy yliopistomaailmaan. Teoksen toimittajien Paula Kyrön ja Anna Ripatin artikkelissa tarkastellaan, miten yrittäjyys on muuttunut integroituen yhteiskunnallisiin ja poliittisiin tavoitteisiin, koulutusjärjestelmään ja tieteelliseen tutkimukseen. Tämän jälkeen he erittelevät yrittäjyyskasvatuksen käsitettä sekä tarkastelevat yrittäjyyskasvatuksen asemaa Suomen koulutusjärjestelmässä. Tarkastelu perustuu jo Kyrön aiemmista julkaisuista tuttuun yrittäjyyden kolmi- tai nelijakoon (ulkoinen yrittäjyys, organisaatioyrittäjyys, omaehtoinen yrittäjyys sekä sisäinen yrittäjyys edellisten vuoropuheluna).

Lopuksi Kyrö ja Ripatti esittävät yrittäjyyskasvatuksen vaatimuksia korkeakoulupedagogiikalle. Kaisu Paasio ja Piia Nurmi raportoivat artikkelissaan valtakunnallisen yrittäjyyden yliopisto-opintoja koskevan tutkimuksensa tuloksia. Jukka Vesalaisen, Kari Ristimäen, Seppo Luodon ja Marko Kohtamäen artikkelissa puolestaan tarkastellaan yliopiston mahdollisuuksia toimia yrittäjyyden ja innovatiivisuuden edistäjänä.

Teoksen II osan Tuulesta energiaa - innovatiivisia puhureja kirjoittajat esittelevät kiinnostavasti käytännön yrittäjyyskasvatuksen kokeiluja. Paula Kyrön artikkelissa käsitellään riskin opettamista ja oppimista. Lauri Tenhusen artikkeli esittelee Hämeen ammattikorkeakoulun starttihautomokokeilua ja erittelee sen suhdetta yrityshautomoihin. Katja Ahlroth, Pertti Manninen, Tarja Nieminen ja Satu Väisänen esittelevät artikkelissaan benchmarkingverkostoa uudenlaisten oppimispaikkojen kehittämisessä toisen asteen ammatillisessa koulutuksessa. Artikkelissa pyritään myös soveltamaan Engeströmin ekspansiivisen oppimisen käsitettä. Toisen osan neljännessä artikkelissa Heleena Lehtonen ja Ilkka Vertanen tarkastelevat koulun toimintakulttuuria ja paikantavat keinoja nuorten syrjäytymisen ehkäisyyn.

Teoksen kolmannessa osassa Ilmasto muuttuu - yrittäjyyskulttuuri kehittyy käsitellään yrittäjyyden ja yrittäjyyskasvatuksen edistämistä keskenään hyvinkin erilaisissa yhteyksissä. Tarja Römer-Paakkanen esittelee artikkelissaan yrittäjyyskasvatukseen profiloituneita ammattikorkeakouluja ja toisen asteen ammatillisia oppilaitoksia, jotka ovat yhdessä Jyväskylän yliopiston kanssa aloittaneet aiheeseen liittyvän opettajien jatkokoulutusprojektin. Virpi Utriainen puolestaan esittelee artikkelissaan Kuntaliiton yrittäjyyskasvatushankkeita, niiden taustaa, tavoitteita ja tehtyjä toimenpiteitä.

Kolmannen osan ja samalla koko kirjan päättävä artikkeli käsittelee naisyrittäjyyttä. Kaisa Hyrsky tarkastelee naisyrittäjyyden suhdetta sosiaalipolitiikkaan, elinikäiseen oppimiseen ja yhteiskunnallisten näkemysten muutoksiin.

Yrittäjyyskasvatuksen uusia tuulia on hyvin toimitettu teos, jonka artikkelit tarjoavat asiantuntevan ja monipuolisen kuvan yrittäjyyskasvatuksen nykyisestä vaiheesta. Lukija jää silti miettimään, voisiko yhteiskuntatieteellinen näkökulma olla kattavammin esillä. Vaikka yrittäjyys on yhteydessä ihmisen persoonallisuuteen ja taloudellisiin seikkoihin, sitä ei voi ymmärtää vain psykologiseksi tai liiketalo- 
udelliseksi ilmiöksi. Yrittäjyys ja yrittäjäksi oppiminen ovat luonteeltaan myös, ja ennen muuta yhteiskunnallisia ilmiöitä. Tämä puoli asiasta ei mielestämme tule teoksessa kovin hyvin esiin. Kysymys kuuluukin, mistä löytyisi sellainen yhteiskuntatieteellinen yrittäjyyskasvatuksen teoria, joka ei olisi liiketaloustiedettä.

Yrittäjyysvalmiuksien opettaminen ja oppiminen edellyttävät toimivien käytänteiden kehittämisen lisäksi, että pystytään luomaan teoreettisesti ja käsitteellisesti toimivia malleja. Kyrön artikkelissa esitelty Ruohotien ja Koirasen (2000) yrittäjyyskasvatuksen keskusteluun tuoma Snown, Cornon ja Jacksonin (1996) taksonomia on yksi yritys vastata tähän haasteeseen. Taksonomiassa ihmisen psyykkisen olemuksen katsotaan muodostuvan persoonallisuudesta ja älykkyydestä, jotka jakautuvat kognitiiviseen, konatiiviseen ja affektiiviseen alueeseen. Kyseessä on klassinen, jo antiikin aikana tunnettu kolmijako (sielunelämän tietopiiri, tunnepiiri ja tahtopiiri), jota käytettiin Lehtovaaran Psykologiaan asti yleisesti suomalaisissakin psykologian oppikirjoissa. Mallia on viimeksi sovellettu 'kolmen komponentin teoriana' erityisesti asennetutkimuksissa, myös kuluttajan käyttäytymisen malleissa (esim. Bagozzi \& Gurhan-Canli \& Priester 2002). Koska kolmijako edustanee väistymässä olevaa kuvaustapaa psykologiassa, sen rinnalla on syytä ottaa myös vaihtoehtoisia ehdotuksia. Kyrön artikkelissa Snown, Cornon ja Jacksonin esittämää taksonomiaa onkin täydennetty: metakognitio on vakiintunut käsite, mutta metaaffektion ja meta-konation käsit- teet kaipaisivat lisäselitystä. Eikö myös affektiivisen ja konatiivisen alueen tietoinen itsesäätely ole metakognitiota?

Uusimmassa kasvatuspsykologian käsikirjassa [Alexander \& Wine (Eds.) 2006] malli on korvattu dispositiokonstruktien, välittävien prosessien ja tulostekijöiden kaaviolla, jossa tekijäryhmät ovat taas kerran aivan uudessa konstellaatiossa (Matthews \& Zeidner \& Roberts 2006, 165). Prosessien korostaminen tuo samalla esille sen, että yrittäjyyden tapahtumien episodinen ja monin tavoin koordinoitu luonne kaipaa nykyistä selvemmin myös etnometodologista, fenomenologis-sosiologista ja mikrohistoriallista selitystapaa, siis lihaa luiden ympärille eli reaalimaailmassa (no, yhä enemmän virtuaalisestikin) toimivia naisia ja miehiä.

Kirjan luettuamme jäimme miettimään, onko yrittäjyyskasvatus aikuiskasvatusta. Yrittäjyyskasvatus leikkaa tällaisia jaotteluja: osa yrittäjyyskasvatuksesta on aikuiskasvatustieteen tutkimusaluetta ja osa ei. Kohderyhmänsä puolesta se useimmissa tapauksissa on aikuiskasvatusta. Valtaosa yrittäjyyskasvatuksestahan kohdistuu edelleen aikuisiin, vaikkakin peruskoulun nykyisen opetussuunnitelman perusteissa (POPS 2004) osallistuva kansalaisuus ja yrittäjyys on niputettu kaikille oppilaille yhteiseksi, läpäisyperiaatteella toteutettavaksi aihekokonaisuudeksi. Koska varhainen oppiminen näkyy myöhemmässä elämässä, myös lapsuus- ja nuoruusiän kasvatuksessa tehtävät ratkaisut ja uudistukset ovat aina merkittäviä aikuiskasvatustieteen kannalta. Toiseen suuntaan tällaista vaikutusyhteyttä ei aina ole: aikuiskasvatus ei välttämättä näy suoraan lasten ja nuorten kehityksessä.

\section{Lähteet}

Alexander, P. A. \& Wine, P. H. (Eds.) (2006). Handbook of Educational Psychology, $2^{\text {nd }}$ Ed. Mahwah, New Jersey: LEA.

Bagozzi, R. \& Gurhan-Canli, Z. \& Priester, J. (2002). The Social Psychology of Consumer Behaviour. Maidenhead: Open U P.

Kyrö, P., Nurmi, K., E. \& Tikkanen, T. (toim.) (1999). Yrittäjyyden askeleita yhteiskunnassa. Helsinki: Yliopistopaino.

Lehtovaara, A. (1968). Psykologia. Jyväskylä: Gummerus.

Matthews, G. \& Zeidner, M. \& Roberts, R. D. (2006). Models for Personality and Affect for Education: A Review and Synthesis. Teoksessa Alexander \& Wine (Eds.) (2006), 163-186.

Opetushallitus (2004), Peruskoulutuksen opetussuunnitelman perusteet 2004. Helsinki: Opetushallitus. HTTP: http:// www.oph.fi/info/ops/ pops_web.pdf (30.11.2006).

Parikka, M. (Toim.) (1997). Kasvu yrittäjyyteen. Jyväskylän yliopisto, Opettajankoulutuslaitos. Opetuksen perusteita ja käytänteitä 27.

Ruohotie, P. \& Koiranen, M. (2000). In the pursuit of conative constructs into entrepreneurship education. Journal of Entrepreneurship Education 3, 9-22.

Snow, R. E. \& Corno, L. \& Jackson, D. (1996). Individual differences in affective and conative functions. Teoksessa Berliner, D. C. \& Calfee, R. C. (Eds.), Handbook of Educational Psychology, 243-310. New York: Macmillan. 